\title{
RHEOLOGICAL BEHAVIOR OF DRILLING FLUIDS CONTAIN ING HYDROPHOBICALLY MODIFIED STARCH FOR FILTRATE REDUCTION
}

\author{
Fernanda Dias ${ }^{1}$, Roberta Souza ${ }^{1}$, Elizabete Lucas ${ }^{1,}$ 2, *
}

https://doi.org/10.23939/chcht12.01.086

\begin{abstract}
In this work, stress-strain graphs of inverse emulsion fluids containing hydrophobically modified starch were plotted from measurements obtained with a coaxial rotating cylinder viscometer, and rheological models were applied. The Bingham model best fitted the experimental results. The correlations obtained by this model allowed calculating plastic viscosity values outside the shear rate sensitivity range of the viscometer and enabled better determination of the conditions for the fluid use.
\end{abstract}

Keywords: fatty acid starch esters, drilling fluid, inverse emulsion (W/O), rheological models.

\section{Introduction}

During the drilling of oil wells, a fluid must be used to cool and lubricate the drill bit, carry the cuttings to the surface and support the borehole wall [1-3]. The fluid chosen must enable rapid, safe, inexpensive and environmentally correct drilling without damaging the rock formation. The cost of drilling fluids accounts for $15-18 \%$ of the total cost of drilling an oil or gas well. According to their continuous phase composition, drilling fluids can be classified as water-based, non-aqueous (fluids based on diesel oil/mineral oil and synthetic fluids), and gas-based [4-7]. Currently, the oil-based systems are mainly composed of water-in-oil (W/O) emulsions, or inverse emulsions, stabilized by an emulsifier along with a series of other specific additives

\footnotetext{
${ }^{1}$ Universidade Federal do Rio de Janeiro (UFRJ), Instituto de Macromoléculas (IMA),

Laboratório de Macromoléculas e Colóides na Indústria do Petróleo (LMCP),

Av. Horácio Macedo, 2030, bloco J, Ilha do Fundão, 21941598,

Rio de Janeiro, Brazil

${ }^{2}$ Universidade Federal do Rio de Janeiro (UFRJ),

COPPE/PEMM/LADPOL,

Av. Horácio Macedo, 2030, Ilha do Fundão, bloco F, 21941972 ,

Rio de Janeiro, Brazil

*elucas@ima.ufrj.br

(c) Dias F., Souza R., Lucas E., 2018
}

responsible for assuring adequate control of the fluid properties $[6,8]$. Fluids based on inverse emulsions have high penetration and lubricity rates, high stability in the well, low corrosion rate, good thermal resistance, high specific density and good tolerance for the presence of salts and contaminants [9].

Modified and unmodified natural polymers (e.g. carboxymethylcellulose, tannins and lignosulfonates) have been widely studied and used industrially in drilling fluids $[6,10]$. Starchy products have attracted interest from researchers and companies due to the abundance of starch in nature and its low cost and total biodegradation in carbon dioxide and water [11, 12]. However, starches have certain limitations in some drilling conditions, requiring chemical modification to obtain more suitable products [13-15].

The performance of a drilling fluid depends mainly on four factors: rheological behavior, density, filtrate loss, and chemical reactivity [16, 17]. Evaluation of the rheological properties of a fluid is of fundamental importance. The loss of these properties can cause destabilization of the inverse emulsion, leading to phase separation and deposition of the thickening agent [18]. Serious problems in the well are caused by high viscosity fluctuations and gelification of the fluid. In general, polymer-based drilling fluids are non-Newtonian, timeindependent and pseudoplastic, and may or may not present residual stresses [19]. The flow behavior of a fluid directly influences the load losses in the pipe, the speed of cuttings transport, the cleaning and erosion of the well, and above all, the success of the drilling operation. The mathematical models most used in the petroleum industry to describe the rheological behavior of drilling fluids relating shear stress $\tau$ and shear rate $\delta$, are [19-20]:

(i) Bingham (or ideal plastic), $\tau=\tau_{0}+\mu \gamma \delta$, where $\tau_{0}-$ yield point (or YP) and $\mu$ - plastic viscosity (PV);

(ii) Ostwald-de-Waale (or power law), $\tau=K \gamma \&$, where $K$ - fluid consistency index and $n$ - flow index, according to which for $n>1$ the fluid is dilatant and for $n<1$ the fluid is pseudoplastic; 
(iii) Herschel-Bulkley (or modified power law), $\tau=\tau_{0}+K \gamma \&$, where $\tau_{0}-$ yield stress, $K-$ fluid consistency index and $n$ - fluid behavior index.

Previous studies have proven that drilling fluids formulated from starchy additives modified with long hydrocarbon chains [21] show a comparable or superior physical-chemical performance in respect to fluids formulated with commercial synthetic polymers [22]. The fundamental rheological properties of these novel fluids have been thoroughly discussed [22]. However, no flow profile was assigned to these systems. Although the literature provides various mathematical expressions for the rheological modeling of non-Newtonian fluids [9, 19], most studies in this area follow standards set by the oil sector, without the concern to find interpretations for the rheological profile of these systems. Under a practical aspect, only knowing the fluid flow behavior it is possible to predict resistance to temperature and pressure conditions in the well. A drilling fluid that loses its rheological properties and needs to be replaced is not desirable. Based on the above considerations, this work is aimed to investigate the fluid flow behavior of the inverse emulsions containing the modified starchy additives through the application of rheological models well established in the literature.

\section{Experimental}

Gelatinized corn starch, $n$-paraffin, organophilic clay, hydrated lime, barium sulfate and a commercial filtrate controller (ECOTROL RD) were donated by Poland Quimica Ltda. (Duque de Caxias, RJ). The hydrophobically modified starch samples were synthesized and characterized in a previous work [21] (Table 1).

The rheological properties plastic viscosity and yield stress of the fluids (aged and non-aged) were determined in a previous work [22] with a Fann model 35-A coaxial rotating cylinder viscometer (Fann Instrument Company, Houston, Texas). The rheological behavior of the fluids was evaluated in this study by plotting flow curves from the rotation and deflection values indicated by the rotating viscometer. The curves of shear stress $\tau$ vs. shear rate $\mathcal{\alpha}_{\text {were obtained by transformation }}$ of the values of rotation $N$ and deflection $\theta$ measured by the viscometer, according to Eqs. (1) and (2) [10, 19].

$$
\begin{gathered}
\tau=0.511 \cdot \theta, \mathrm{m} \cdot \mathrm{Pa} \\
\gamma \delta=1.703 \cdot N, \mathrm{~m} \cdot \mathrm{s}^{-1}
\end{gathered}
$$

The rheological models applied to the data were the Bingham, Ostwald-de-Waale and Herschel-Bulkley, as described in the introduction section.

\section{Results and Discussion}

The rheological behavior of oil-based fluids is highly complex and depends on the interplay of temperature, pressure and shear rate. Among the main parameters that affect the rheological properties are viscosity of the continuous phase, overall viscosity, volumetric fraction, average size and size distribution of particles in the dispersed phase, the nature and concentration of the emulsifier and the size and shape of the dispersed solids [23]. Careful selection of additives that are suitable for wells being drilled under severe environmental conditions is fundamental to control the rheological and filtration properties of the fluid [24].

The Bingham and Ostwald-de-Waale models are valid for laminar flows. These models cannot be applied to any fluid or any shear rate interval. The HerschelBulkley model, in turn, because it considers three parameters, is more complete and usually provides a better fit to the rheological data [25]. Nevertheless, deficiencies of the Bingham, Ostwald-de-Waale, and Herschel-Bulkley continue to be observed for flows under high strain rates $\left(\geq 1000 \mathrm{~s}^{-1}\right)$.

The fundamental rheological properties that are associated with drilling fluid performance are the flow behavior index $(n)$, flow consistency index $(K)$, apparent viscosity $(\mathrm{AV})$, plastic viscosity $(\mathrm{PV})$, yield point (YP) and gel force $[1,22]$. The flow behavior index $n$ indicates how far the fluid is from having Newtonian behavior. If the value of $n$ is near one, then the fluid behavior is nearly Newtonian. The parameter $K$, in turn, indicates the degree of the fluid's resistance to flow. The apparent viscosity (AV) of a non-Newtonian fluid can be defined as the viscosity of a fluid with Newtonian behavior at a determined shear rate [26]. The plastic viscosity (PV) is the theoretical viscosity of the fluid at an infinite shear rate. This rheological parameter increases with the viscosity of the organic base, water concentration and concentration and distribution profile of the solid particles [18]. The yield point (YP) represents the minimum shear stress value that must be applied for the fluid to start flowing. This parameter provides an indication of the pseudoplastic characteristics of the fluid and its ability to carry solids in suspension. The gel force also has a rheological nature and indicates the degree of gelification associated with the electrical interaction of the particles dispersed in the medium [9]. The initial gel (IG) parameter measures the fluid resistance against entering the flow regime, while the final gel (FG) parameter measures the fluid resistance to starting to flow again after a period of rest [19]. 


\section{Degrees of chemical modification of starch samples modified with hydrocarbon chains [21]}

\begin{tabular}{|c|c|c|c|}
\hline Sample code & Chemical structure & Pendent chain $R$ & Degree of chemical modification \\
\hline SVS-01 & \multirow{6}{*}[{}_{\mathrm{HO}}^{\mathrm{OH}}]{$\left._{\mathrm{O}}^{\mathrm{OH}}\right]_{1}$} & \multirow{3}{*}{ - } & 0.65 \\
\hline SVS-02 & & & 2.64 \\
\hline SVS-03 & & & 2.96 \\
\hline SVL-01 & & \multirow{3}{*}{$\mathrm{C}_{12}$} & 0.62 \\
\hline SVL-02 & & & 2.75 \\
\hline SVL-03 & & & 2.94 \\
\hline
\end{tabular}

In the previous work [22], samples of chemically modified starch were used to formulate drilling fluids, which were tested before and after aging concerning the parameters mentioned here. The results depended on the molecular structure and concentration, and fluids were obtained with better performance than that of a commercial formulation.

The literature contains mathematical expressions with many levels of complexity for rheological modeling of non-Newtonian fluids [9, 19, 27]. Some of these are mere attempts at linear fit using empirical relations between shear stress and shear rate, while others are based theoretically on statistical mechanisms. Despite the relevance of the flow behavior of drilling fluids, most of the studies in this area follow standards established by the petroleum sector, without concern for finding interpretations of the rheological profile of these systems. Non-aqueous fluids with low toxicity are rheologically well described by the Bingham and Herschel-Bulkley mathematical models [9, 28-29]. The Bingham model is most often employed by the petroleum industry because it is a simple non-Newtonian model $[30,31]$. This model is only valid for laminar flows and is governed by two rheological parameters: plastic viscosity (PV) and yield

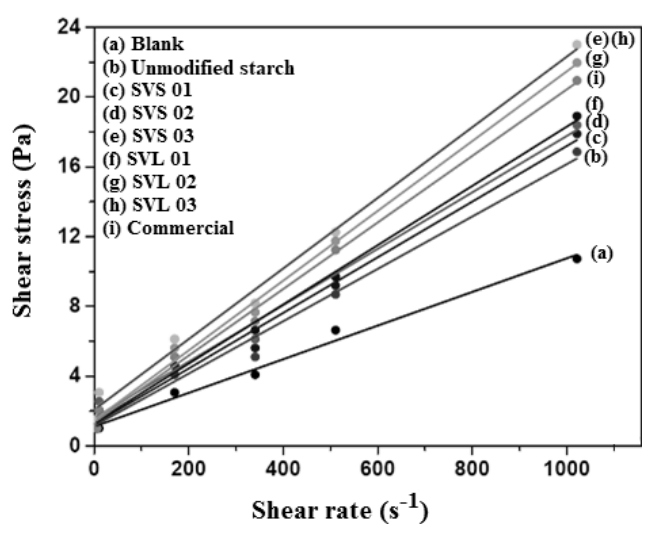

Fig. 1. Curves of shear stress vs. shear rate obtained for non-aged fluids formulated with $8.5 \mathrm{~kg} / \mathrm{m}^{3}$ of filtrate control additive point (YP) [19]. Drilling muds based on inverse emulsions behave according to the Bingham plastic model for shear rates in the range from 0 to $1800 \mathrm{~s}^{-1}$ [32].

In one study, the Bingham model was not able to adequately describe the rheology of inverse emulsion fluids at temperatures higher than $473 \mathrm{~K}$ and pressures greater than $100 \mathrm{MPa}$ [33]. Two different rheological behavior regimes have been observed for some oil-based systems: a Newtonian profile at low shear rates and behavior as a Herschel-Bulkley fluid at high shear rates [28]. It has also been found that the critical shear rate between the two regimes is a function of temperature and that the change of regime corresponds to different mud structures. In that study, the behavior of clay particles under low shear rates was determined by surface forces of attraction and repulsion, and the viscosity of the system remained relatively high. An increase in shear rate favored the gradual alignment of the clay particles in the flow and the rheological parameter of the mud started to be influenced only by the concentration of solids in suspension and no longer by their interaction [9]. An ideal drilling fluid should have an invariable rheological profile (flat rheology) for a broad range of temperatures and pressures in the well [18]/

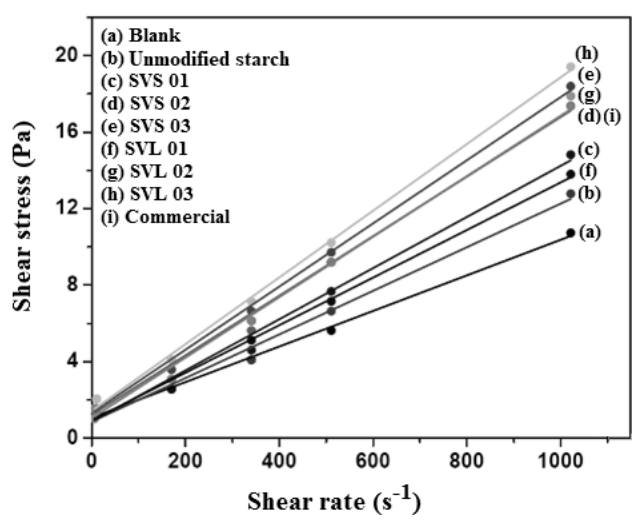

Fig. 2. Curves of shear stress $v s$. shear rate $\left(\mathrm{s}^{-1}\right)$ obtained for aged fluids formulated with $8.5 \mathrm{~kg} / \mathrm{m}^{3}$ of filtrate control additive 


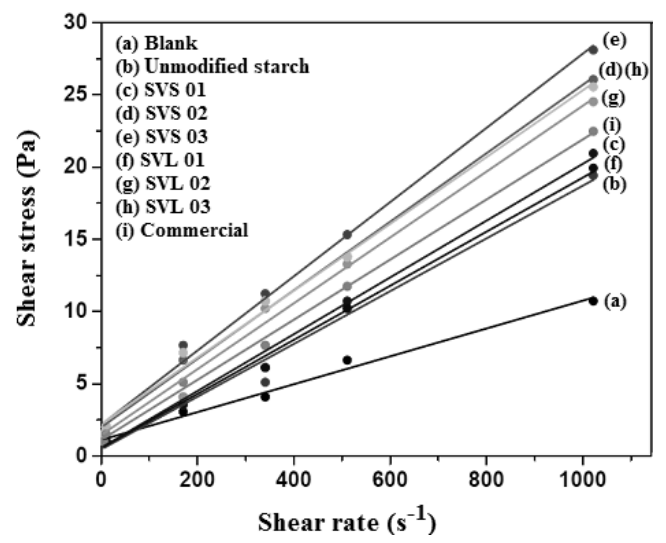

Fig. 3. Curves of shear stress $v$ s. shear rate obtained for non-aged fluids formulated with $14.2 \mathrm{~kg} / \mathrm{m}^{3}$ of filtrate control additive

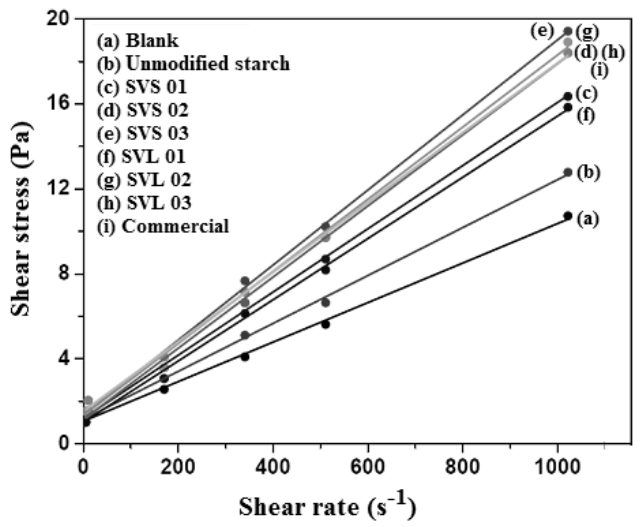

Fig. 4. Curves of shear stress $v s$. shear rate obtained for aged fluids formulated with $14.2 \mathrm{~kg} / \mathrm{m}^{3}$ of filtrate control additive

Table 2

Comparison between the rheological parameters estimated by the model and the experimental values read from a Fann 35-A viscometer for the non-aged fluids containing $8.5 \mathrm{~kg} / \mathrm{m}^{3}$ ) of filtrate controller

\begin{tabular}{|c|c|c|c|c|c|c|c|}
\hline \multirow{2}{*}{ Filtrate controller } & \multicolumn{3}{|c|}{ Bingham Model } & \multicolumn{2}{|c|}{ Fann 35-A [22] } & \multirow{2}{*}{$\frac{Y P_{M O D E L}}{Y P_{F A N N 35-A}}$} & \multirow{2}{*}{$\frac{P V_{M O D E L}}{P V_{F A N N 35-A}}$} \\
\hline & $R^{2}$ & $\mathrm{YP}(\mathrm{SD}), \mathrm{Pa}$ & $\mathrm{PV}$ (SD), $\mathrm{Pa} \cdot \mathrm{s}$ & YP, Pa & $\mathrm{PV}, \mathrm{Pa} \cdot \mathrm{s}$ & & \\
\hline Blank & 0.988 & $1.12(0.233)$ & 0.009 (4.7 E-4) & 2.40 & 0.008 & 0.468 & 1.125 \\
\hline Starch & 0.984 & $1.16(0.424)$ & 0.015 (8.6 E-4) & 0.48 & 0.016 & 2.409 & 0.938 \\
\hline SVS-01 & 0.986 & $1.26(0.420)$ & $0.016(8.5 \mathrm{E}-4)$ & 0.48 & 0.017 & 2.630 & 0.941 \\
\hline SVS-02 & 0.983 & $1.61(0.468)$ & $0.016(9.5 \mathrm{E}-4)$ & 0.96 & 0.019 & 1.681 & 0.842 \\
\hline SVS-03 & 0.991 & $2.09(0.415)$ & $0.020(8.5 \mathrm{E}-4)$ & 1.44 & 0.021 & 1.453 & 0.952 \\
\hline SVL-01 & 0.994 & $1.33(0.278)$ & 0.017 (5.6 E-4) & 0.48 & 0.018 & 2.770 & 0.944 \\
\hline SVL-02 & 0.994 & $1.49(0.334)$ & $0.020(6.8 \mathrm{E}-4)$ & 1.44 & 0.020 & 1.035 & 1.000 \\
\hline SVL-03 & 0.991 & $2.09(0.415)$ & $0.020(8.4 \mathrm{E}-4)$ & 1.44 & 0.021 & 1.453 & 0.952 \\
\hline Comm & 0.994 & $1.38(0.313)$ & 0.019 (6.4 E-4) & 1.44 & 0.019 & 0.958 & 1.000 \\
\hline
\end{tabular}

Notes: YD - yield point; PV - plastic viscosity; SD - standard deviation.

Table 3

Comparison between the rheological parameters estimated by the model and the experimental values read from a Fann 35-A viscometer for the aged fluids containing $8.5 \mathrm{~kg} / \mathrm{m}^{3}$ ) of filtrate controller

\begin{tabular}{|c|c|c|c|c|c|c|c|}
\hline \multirow[b]{2}{*}{ Filtrate controller } & \multicolumn{3}{|c|}{ Bingham Model } & \multicolumn{2}{|c|}{ Fann 35-A [22] } & \multirow{2}{*}{$\frac{Y P_{M O D E L}}{Y P_{F A N N 35-A}}$} & \multirow{2}{*}{$\frac{P V_{M O D E L}}{P V_{F A N N 35-A}}$} \\
\hline & $R^{2}$ & YP(SD), Pa & $\mathrm{PV}$ (SD), Pa.s & $\mathrm{YP}, \mathrm{Pa}$ & $\mathrm{PV}, \mathrm{Pa} \cdot \mathrm{s}$ & & \\
\hline Blank & 0.995 & $1.07(0.139)$ & $0.009(2.8 \mathrm{E}-4)$ & 0.48 & 0.010 & 2.228 & 0.900 \\
\hline Starch & 0.988 & $0.86(0.267)$ & $0.011(5.4 \mathrm{E}-4)$ & 0.48 & 0.012 & 1.789 & 0.917 \\
\hline SVS-01 & 0.990 & $0.86(0.292)$ & $0.013(5.9 \mathrm{E}-4)$ & 0.48 & 0.014 & 1.800 & 0.929 \\
\hline SVS-02 & 0.990 & $1.21(0.342)$ & $0.016(6.9 \mathrm{E}-4)$ & 0.96 & 0.016 & 1.264 & 1.000 \\
\hline SVS-03 & 0.995 & $1.31(0.249)$ & $0.016(5.1 \mathrm{E}-4)$ & 0.96 & 0.017 & 1.373 & 0.941 \\
\hline SVL-01 & 0.995 & $0.92(0.203)$ & $0.012(4.1 \mathrm{E}-4)$ & 0.48 & 0.013 & 1.931 & 0.923 \\
\hline SVL-02 & 0.995 & $0.81(0.249)$ & $0.016(5.1 \mathrm{E}-4)$ & 0.48 & 0.017 & 1.683 & 0.941 \\
\hline SVL-03 & 0.998 & $1.42(0.174)$ & $0.017(3.5 \mathrm{E}-4)$ & 0.96 & 0.018 & 1.485 & 0.944 \\
\hline Comm & 0.994 & $1.05(0.261)$ & $0.016(5.3 \mathrm{E}-4)$ & 0.96 & 0.016 & 1.092 & 1.000 \\
\hline
\end{tabular}

Notes: YD - yield point; PV - plastic viscosity; SD - standard deviation. 
Comparison between the rheological parameters estimated by the model and the experimental values read from a Fann 35-A viscometer for the non-aged fluids containing $14.2 \mathrm{~kg} / \mathrm{m}^{3}$ ) of filtrate controller

\begin{tabular}{|c|c|c|c|c|c|c|c|}
\hline \multirow{2}{*}{ Filtrate controller } & \multicolumn{3}{|c|}{ Bingham Model } & \multicolumn{2}{|c|}{ Fann 35-A [22] } & \multirow{2}{*}{$\frac{Y P_{M O D E L}}{Y P_{F A N N 35-A}}$} & \multirow{2}{*}{$\frac{P V_{M O D E L}}{P V_{F A N N 35-A}}$} \\
\hline & $R^{2}$ & $\mathrm{YP}(\mathrm{SD}), \mathrm{Pa}$ & $\mathrm{PV}$ (SD), $\mathrm{Pa} \cdot \mathrm{s}$ & YP, Pa & $\mathrm{PV}, \mathrm{Pa} \cdot \mathrm{s}$ & & \\
\hline Blank & 0.988 & $1.12(0,23)$ & 0.009 (4.7 E-4) & 2.40 & 0.008 & 0.468 & 1.125 \\
\hline Starch & 0.984 & $0.46(0,50)$ & $0.018(1.0 \mathrm{E}-3)$ & 0.96 & 0.018 & 0.484 & 1.000 \\
\hline SVS-01 & 0.993 & $0.58(0,36)$ & 0.019 (7.3 E-4) & 0.48 & 0.020 & 1.215 & 0.950 \\
\hline $\begin{array}{l}\text { SVS-02 } \\
\end{array}$ & 0.996 & $2.00(0,33)$ & 0.024 (6.6 E-4) & 1.44 & 0.024 & 1.393 & 1.000 \\
\hline SVS-03 & 0.994 & $2.17(0,42)$ & $0.026(8.6 \mathrm{E}-4)$ & 2.39 & 0.025 & 0.908 & 1.040 \\
\hline SVL-01 & 0.995 & $0.56(0,28)$ & 0.019 (5.6 E-4) & 0.48 & 0.019 & 1.169 & 1.000 \\
\hline SVL-02 & 0.991 & $1.46(0,47)$ & $0.022(9.6 \mathrm{E}-4)$ & 1.91 & 0.022 & 0.764 & 1.000 \\
\hline SVL-03 & 0.992 & $2.20(0,44)$ & $0.023(8.9 \mathrm{E}-4)$ & 1.91 & 0.023 & 1.148 & 1.000 \\
\hline Comm & 0.997 & $1.12(0,22)$ & $0.021(4.4 \mathrm{E}-4)$ & 0.96 & 0.021 & 1.171 & 1.000 \\
\hline
\end{tabular}

Notes: YD - yield point; PV - plastic viscosity; SD - standard deviation.

Table 5

Comparison between the rheological parameters estimated by the model and the experimental values read from a Fann 35-A viscometer for the aged fluids containing $14.2 \mathrm{~kg} / \mathrm{m}^{3}$ ) of filtrate controller

\begin{tabular}{|c|c|c|c|c|c|c|c|}
\hline \multirow{2}{*}{ Filtrate controller } & \multicolumn{3}{|c|}{ Bingham Model } & \multicolumn{2}{|c|}{ Fann 35-A [22] } & \multirow{2}{*}{$\frac{Y P_{M O D E L}}{Y P_{F A N N 35-A}}$} & \multirow{2}{*}{$\frac{P V_{\text {MODEL }}}{P V_{\text {FANN35-A }}}$} \\
\hline & $R^{2}$ & $\mathrm{YP}(\mathrm{SD}), \mathrm{Pa}$ & $\mathrm{PV}$ (SD), Pa·s & $\mathrm{YP}, \mathrm{Pa}$ & $\mathrm{PV}, \mathrm{Pa} \cdot \mathrm{s}$ & & \\
\hline Blank & 0.995 & $1.07(0,139)$ & 0.009 (2.8 E-4) & 0.48 & 0.010 & 2.225 & 0.900 \\
\hline Starch & 0.997 & $1.15(0,129)$ & $0.011(2.6 \mathrm{E}-4)$ & 0.48 & 0.012 & 2.409 & 0.917 \\
\hline SVS-01 & 0.997 & $1.19(0,149)$ & 0.015 (3.0 E-4) & 0.96 & 0.015 & 1.249 & 1.000 \\
\hline SVS-02 & 0.995 & $1.15(0,256)$ & 0.017 (5.2 E-4) & 0.96 & 0.017 & 1.201 & 1.000 \\
\hline SVS-03 & 0.996 & $1.35(0,225)$ & 0.018 (4.6 E-4) & 0.96 & 0.018 & 1.405 & 1.000 \\
\hline SVL-01 & 0.997 & $1.01(0,178)$ & 0.014 (3.6 E-4) & 0.48 & 0.015 & 2.119 & 0.933 \\
\hline SVL-02 & 0.995 & $1.33(0,263)$ & 0.017 (53 E-4) & 0.48 & 0.018 & 2.768 & 0.944 \\
\hline SVL-03 & 0.998 & $1.52(0,137)$ & $0.016(2.8 \mathrm{E}-4)$ & 0.96 & 0.017 & 1.590 & 0.941 \\
\hline Comm & 0.998 & $1.53(0,137)$ & $0.016(2.8 \mathrm{E}-4)$ & 0.96 & 0.015 & 1.594 & 1.067 \\
\hline
\end{tabular}

Notes: YD - yield point; PV - plastic viscosity; SD - standard deviation.

Figs. 1-4 show the flow curves obtained for the non-aged and aged fluids formulated with 8.5 and $14.2 \mathrm{~kg} / \mathrm{m}^{3}$ of filtrate control additive, respectively. The fluid was tested without filtrate control additive (called blank) and with a commercial filtrate controller, with unmodified starch and six modified starch samples. The shear stress and shear rate values were calculated by the transformation of rotations $N$ and deflections $\theta$ given by the rotary viscometer (Eqs. (1) and (2)). All the tested fluids presented Bingham behavior, irrespective of the type and concentration of the starch derivative included in the formulation and the rolling conditions. The Bingham rheological model best represented the experimental data, showing the highest coefficients of correlation $R^{2}$ and lowest standard deviations (SD).

Tables 2-5 report the values of plastic viscosity, yield point, correlation coefficient, and standard deviation estimated by linear adjustment of the experimental data using the equation of the Bingham model.
The linear fitting of the data was carried out with the objective of observing a possible equivalence between the rheological properties calculated by the model and the measures obtained from the Fann 35-A viscometer. The proportionality between the experimental values (Fann 35-A) and values calculated by the model (Bingham method) were expressed as ratios:

$$
\frac{P V_{M O D E L}}{P V_{F A N N 35-A}} \text { and } \frac{Y P_{M O D E L}}{Y P_{F A N N 35-A}}
$$

The rheological measures obtained with the Fann 35-A viscometer are not able to quantify dependencies of the viscosity values with high and low shear rates [28]. The results for $\mathrm{PV}\left(\mathrm{L}_{600}-\mathrm{L}_{300}\right)$ and $\mathrm{YP}\left(\mathrm{L}_{300}-\mathrm{PV}\right)$ calculated from the data measured by this device are only valid for shear rates in the standard API interval (300$600 \mathrm{rpm}$ ) [9]. Viscosity readings obtained from this rotary viscometer outside this range are unreliable due to the significantly associated error. The Bingham model, in 
contrast, calculates PV and YP values in a broader shear rate interval of 3-600 rpm. According to the results shown in Tables 2-5, the ratios of the parameter PV (model/experimental) are very near 1.0 for all the systems investigated, indicating good reliability of the measured values. However, the same equivalence was not observed between the experimentally obtained YP values and those calculated by the model, except for the commercial filtrate controller. The commercial additive practically showed no deviations for PV and YP model/experimental correlations, regardless of the type of formulation tested. For the other systems, however, significant deviations from 1.0 were observed about the YP model/experimental ratio. Concerning this parameter, deviations in the range of $0.23-1.0$ were detected for the formulations prepared from modified starches additives. Concerning the YP parameter, it is interesting to note that the formulations prepared from unmodified starch exhibited superior deviations values to those containing the modified starches. This variation in the YP estimation can be explained by one of the limitations associated with the Bingham model [34]. Non-Newtonian fluids tend to have a well-defined pseudoplastic character at low shear rates, but stray from the linear behavior predicted by the Bingham model for extrapolated YP values (linear coefficient of the model's equation).

\section{Conclusions}

In drilling-fluid rheological characterization, choosing a proper rheological model and obtaining rheological parameters with viscometers are essential. The flow behavior directly influences the drilling operation, as in the pipe load losses and cuttings transport speed. A proper relationship between YP and VP is significant for preventing common drilling problems. All systems investigated in the present study were well fitted by the Bingham model approach, regardless of the type and concentration of the starch derivative included in the formulation and the rolling conditions. The developed fluids performed well within the desired limits and followed the tendency of the majority of drilling fluids already used. For more severe drilling conditions, it is possible that the Bingham model tends to deviate from the experimental data. In addition to making these systems technically competitive, the additives based on starch fatty esters also show a favorable environmental profile. The future demand of more complex drilling muds for deep and ultra-deep water drilling will require the knowledge of these fluids at a molecular level.

\section{Acknowledgements}

We thank CNPq (307193/2016-0), CAPES and FAPERJ (E-26/201.233/2014) for financial support.

\section{References}

[1] Thomas J.: Fundamentos da Engenharia de Petróleo, Interciência, Rio de Janeiro 2001.

[2] Lucas E., Ferreira L., Khalil C.: Polymers Applications in Petroleum Production [in:] Mark H. (Ed.), Encyclopedia of Polymer Science and Technology. John Wiley \& Sons, Inc. 2015. https://doi.org/10.1002/0471440264.pst641

[3] Santana K., Fagundes F., Carvalho L. et al.: Macromol. Symp., 2016, 367, 151. https://doi.org/10.1002/masy.201500131

[4] Figueiredo M., Almeida L., Costa F. et al.: Macromol. Symp., 2006, 1, 260. https://doi.org/10.1002/masy.200651336

[5] Spinelli L., Aquino A., Lucas E., et al.: Polym. Eng. Sci., 2008, 48, 1885. https://doi.org/10.1002/pen.21078

[6] Martins A., Waldmann A., Massarani G.: J. Porous Media, 2010, 13, 1255. https://doi.org/10.1615/JPorMedia.v13.i5.20

[7] Khodja M., Khodja-Saber M., Canselier J. et al.: Drilling Fluid Technology: Performances and Environmental Considerations, [in:] Fuerstner I. (Ed.), Products and Services; from R\&D to Final Solutions. Sciyo Publisher 2010, 227. https://doi.org/10.5772/10393 [8] Mahto V., Sharma V.: J. Petrol. Sci. Eng., 2004, 45, 123. https://doi.org/10.1016/j.petrol.2004.03.008

[9] Caenn R., Darley H., Gray G.: Composition and Properties of Drilling and Completion Fluids, $6^{\text {th }}$ edn. Gulf Professional Publishing, Houston 2011.

[10] Balaban R., Vidal E., Borges M.: Appl. Clay Sci., 2015, 105-

106, 124. https://doi.org/10.1016/j.clay.2014.12.029

[11] Lörcks J.: Polym. Degrad. Stabil., 1998, 59, 245.

https://doi.org/10.1016/S0141-3910(97)00168-7

[12] Amanullah M., Yu L.: J. Petrol. Sci. Eng., 2005, 48, 199.

https://doi.org/10.1016/j.petrol.2005.06.013

[13] Miladinov V., Hanna M.: Ind. Crop. Prod., 2000, 11, 51.

https://doi.org/10.1016/S0926-6690(99)00033-3

[14] Fuda E., Jauregi P.: J. Chromatogr. B, 2006, 843, 317.

https://doi.org/10.1016/j.jchromb.2006.06.032

[15] Simi C., Abraham T.: Bioprocess Biosystem. Eng., 2007, 30,

173. https://doi.org/10.1007/s00449-007-0112-5

[16] Darley H., Gray G.: Composition and Properties of Drilling and Completion Fluids, $5^{\text {th }}$ edn. Gulf Publishing Company, Houston 1988. [17] Caenn R., Chillingar G. V.: J. Petrol. Sci. Eng., 1996, 14, 221. https://doi.org/10.1016/0920-4105(95)00051-8

[18] Wagle V., Maghrabi S., Teke K., Gantepla A.: SPE Oil and Gas India Conference and Exhibition. India, Mumbai, 28-30 March 2012. https://doi.org/10.2118/153705-MS

[19] Machado J.: Reologia e escoamento de fluidos, Rio de Janeiro, Interciência, 2002.

[20] Santoyo E., Santoyo-Gutiérrez S., Garcia A. et al:: Appl.

Therm. Eng., 2001, 21, 283. https://doi.org/10.1016/S1359-

4311(00)00003-X

[21] Dias F., Souza R., Lucas E.: Chem. Chem. Technol., 2013, 7, 451.

[22] Dias F., Souza R., Lucas E.: Fuels, 2015, 140, 711.

https://doi.org/10.1016/j.fuel.2014.09.074

[23] Maglione, R., Robotti, G., Romagnoli R.: SPE J., 2000, 5, 377. https://doi.org/10.2118/66285-MS. 
[24] De Stefano G., Stamatakis E., Young S.: SPE Drill Comp., 2013, 28, 86. SPE-153709-PA. http://dx.doi.org/10.2118/153709-PA.

[25] Hamed S., Belhadri M.: J. Petrol. Sci. Eng., 2009, 67, 84. https://doi.org/10.1016/j.petrol.2009.04.001

[26] Stefan P.: Cerâmica, 1996, 12, 266.

[27] Iscan A., Kok M.: Energ. Source. A, 2007, 29, 939. https://doi.org/10.1080/00908310600713966

[28] Herzhaft B., Rousseau L., Neau L. et al.: SPE J., 2003, 8, 211, SPE-86197-MS. https://doi.org/10.2118/86197-MS.

[29] Shah S., Shanker N., Ogugbue C.: Future Challenges of Drilling Fluids and Their Rheological Measurements [in:] American Association of Drilling Engineers (AADE) Fluids Conference and Exhibition. USA, Houston, 6-7 April 2010, AADE-10-DF-HO-41. [30] Amorim L., Barbosa M., Ferreira H.: Revista Matéria, 2008, 13, 209. https://doi.org/10.1590/S1517-70762008000100026 [31] Amorim L., Farias K., Viana J. et al.: Cerâmica, 2005, 51, 128. https://doi.org/10.1590/S0366-69132005000200010

[32] Politte M.: SPE/IADC Drilling Conference. Louisiana, New Orleans, 5-8 March 1985, SPE 13458.

https://doi.org/10.2118/13458-MS

[33] Bailey T., Bern P., McEwan F.: SPE J., 1986, 1, SPE 13001PA. https://doi.org/10.2118/13001-PA
[34] Gonçalves R.: Thesis for MSc degree, Universidade Federal Rural do Rio de Janeiro, Seropédica, Rio de Janeiro 2008.

Received: August 03, 2017 /Revised: September 11, 2017 / Accepted: November 27, 2017

\section{РЕОЛОГІЧНЕ ПОВЕДІНКА БУРОВИХ РОЗЧИНІВ 3 ГІДРОФОБНО-МОДИФІКОВАНИМ КРОХМАЛЕМ ДЛЯ ЗМЕНШЕННЯ ФІЛЬТРАТУ}

Анотація. Для інверсних емульсій, що містять гідрофобно-модифікований крохмаль, побудовано діаграми напругидеформачій з використанням коаксіального ииліндрового віскозиметра, та застосовано реологічні моделі. Встановлено, щзо модель Бінгама найбільш відповідає отриманим результатам. Корелячії, отримані за ијією моделлю, дають можливість розрахувати величини пластичної в'язкості за межсами діапазону чутливості віскозиметра $і$ полегшують визначення умов для використання рідини.

Ключові слова: естери жсирних кислот крохмалю, бурова рідина, інверсна емульсія (В/O), реологічні моделі. 